\title{
Analyzing The Productive Disposition And Its Correlation With Mathematics Achievement Of Islamic Junior High School Students
}

\author{
(1) Luluk S. Husniah, (2) Rusijono, (3) Fajar Arianto \\ Faculty of Education Technology, State University of Surabaya Indonesia
}

\begin{abstract}
Productive disposition refers to the tendency to see sense in mathematics, to perceive it as both useful and worthwhile, to believe that steady effort in learning mathematics pays off, and to see oneself as an effective learner and a doer of mathematics. Disposition refers not simply to attitudes, but to a tendency to think and to act in positive ways. This study aimed to analyze the productive disposition and its correlation with mathematics achievement of Islamic Junior High School students. A total of 149 Islamic Junior High School students in Jombang was procured as samples. Statistical analysis was based on the Spearman rank correlation and on the ttest. The findings showed that at average, the productive disposition of the Islamic Junior High School students were categorizing low.

Furthermore, there was a positive and significant correlation between the productive disposition and mathematics achievement of the Islamic Junior High School students, though the correlation coefficient was not high. An observation was also made to analyze this correlation, and it was found that though some students have good the productive disposition, sometimes they could not do the tests well, because of the condensed curriculum, and also their social activities, which make their mathematics achievement become lower. Another finding was that Islamic Junior High School students need teachers with various mathematics teaching strategies for them to gain better the productive disposition.
\end{abstract}

Key words: Productive Disposition, Mathematics Achievement.

DOI: $10.7176 / \mathrm{JEP} / 12-10-16$

Publication date: April $30^{\text {th }} 2021$

\section{Introduction}

Studies have been made along decade, according to student mathematics achievement through a specific (mathematics, communication, reasoning, connection, or problem solving ability) or in general evaluation. Researcher tried to increase the student mathematics achievement through various learning strategy implementation. As the result, a conclusion has been made that student mathematics achievement were increased through the learning strategy implementation. Furthermore, the extent of constructing differed in students' mathematics learning strategies is strongly associated with their level of mathematics achievement (Thiessen and Blasius, 2008). According to the NCTM, instead of making evaluationofn the specific mathematics ability mentioned above, we have to evaluate the student productive disposition as well. Generally, disposition is a tendency to do or not to do things, an aspect of motivation (Zidniyati, 2007). Productive disposition refers not simply to attitudes, but a tendency to think and to act in positive ways towards mathematics as something logic, useful and beneficial (NCTM, 1989; Syaban, 2008). Productive disposition has some aspects, that is: confidence, flexibility, willingness to persevere, interest, inclination to monitor and reflect, valuing the application of mathematics, and appreciation of the role of mathematics (NCTM, 1989). Some other aspects which also important known as affective aspects was added in this study, those aspects are: attitude or predisposition, self concept, and moral (Diknas, 2008). All these aspects will apparent in every aspect of student mathematical activities.

Islamic Junior High School students are categorized as adolescent. According to Finder adolescent is often portrayed as a period of immaturity, instability, and turbulence (Phelps, 2005) which can be seen in school as 
well. Furthermore, Chandler and Mahar found out that online communities affect adolescent much because it offered them richer and more satisfying lives than they had in real time (Phelps, 2005). All this condition will affect their learning achievements, included mathematics achievement. The aim of this study is to know the productive disposition of Islamic Junior High School student and its correlation with their mathematics achievement. The productive disposition was measured through a productive disposition (PD) instrument consist of 20 statements included all the aspects mentioned above, while the mathematics achievement was measured through mathematics tests.

\section{Productive Disposition}

A sociocultural and socioconstructivist perspective of learning informed the design of clubs and related research. Mathematics learning is considered a social activity in which learners actively construct meaning. Additionally, learning involves developing dispositions and ways of being (Gresalf \& Cobb 2006) and our intervention work assumes that learning to learn can be actively and deliberately supported by developing productive learning habits (Claxton \& Carr 2004). Because mathematics is a strongly hierarchical subject, learners build new knowledge on previously learnt knowledge as they progress towards increasingly abstract levels and stages of numerical strategies, conceptual place value and multiplicative reasoning. Wright et al. (2006a) Learning Framework in Number and the related Mathematics Recovery Program (Wright et al. 2006b) informs many of the assessments and learning activities used in the broader project and in clubs. Additionally, the five-stranded definition of mathematical proficiency put forth by Kilpatrick, Swafford \& Findell (2001) guides project work. That is, mathematically Proficiency involves the development of five interconnected strands, namely, procedural fluency, conceptual understanding, adaptive reasoning, strategic competence and productive disposition. Productive disposition, as Kilpatrick (2001) et al. define it:

"Refers to the tendency to see sense in mathematics, to perceive it as both useful and worthwhile, to believe that steady effort in learning mathematics pays off, and to see one self as an effective learner and doer of mathematics (p. 131)".

Kilpatrick et al. (2001: 131) said that developing a productive disposition requires 'habituation of someone to understand mathematics, to know the usefulness of mathematics, and how one is able to appreciate the benefits of mathematics for themselves'. They argue that productive dispositions develop when other strands develop. For example, when students build strategic competencies in solving non-routine problems, their attitudes and beliefs about themselves as learners of mathematics become more positive.

Kilparik et al. (2001) said that productive disposition is a positive attitude and habit to see mathematics as logical something and useful for human life. While the indicator is: 1. Enthusiastic in mathematics learning. 2. Attentive in mathematics learning. 3. Persistent and diligent in dealing with problems. 4. Full of confidence in learning and solving problems. 5. Flexible and open. 6. Have high curiosity. 7. Ability to share opinions with others.

Productive disposition develops is influenced by the inner will. For example, when students build strategic competencies in solving non-routine problems, their attitudes and beliefs about themselves as learners of mathematics become more positive. The more mathematical concepts they understand, the more mathematical sense makes. Conversely, when students are rarely given the challenge of a mathematical problem to solve, they expect memorization and not a sense that makes the way to learning mathematics, and they begin to lose their 
confidence as students. Similarly, when students see themselves being able to learn mathematics and use it to solve problems, they can further develop procedural fluency or their adaptive reasoning abilities. Students' disposition of mathematics is a major factor in determining their educational success. Students who see their mathematical abilities as fixed questions and tests as measuring their abilities rather than providing opportunities for learning tend to avoid problems that are challenging and easily carried away by the failure. Students who see abilities as expanded in response to experience and training are more likely to look for challenging situations and learn from them. Cross-cultural research studies have found that US children are more likely to link success in school to ability than effort when compared to students in East Asian countries.Most US children enter schools who want to learn and with a positive attitude towards mathematics. It is very important that they face good mathematics teaching in the early grades. Otherwise, these positive attitudes can turn sour when they see themselves as poor students and mathematics as unreasonable, arbitrary, and impossible to learn except by memorizing.

\section{Mathematics Achievement}

Mathematics achievement is a form of ability shown by students in learning mathematics. Poerwadarminta (1974) defines that achievement is the result that has been achieved by someone in an effort that is done or done. The definition above is in line with the opinion of Winkel (1986) which states that achievement is evidence of effort achieved. The term achievement is always used in knowing the success of student learning in school. Learning achievement is a value that shows the highest results in learning achieved according to the ability of students to do something at a certain time.

Furthermore Soejanto (1979) states that learning achievement can also be seen as a reflection of learning shown by students through changes in the field of knowledge/ understanding, skills, analysis, synthesis, evaluation and values and attitudes. Student learning achievement is determined by two factors, namely internal and extreme. Internal factors are factors that originate or originate from the students themselves, while external factors are factors that originate or originate from outside students. Internal factors include the prerequisites for learning, namely the knowledge that is already possessed by students before following the next lesson, the learning skills possessed by students, which include ways related to the following subjects, doing assignments, reading books, group learning, preparing for exams, following up on exam results and looking for learning resources, students' personal conditions which include health, intelligence, attitudes, ideals, and relationships with others. External factors include the teaching and learning process, the learning facilities they have, the learning environment, and the socioeconomic conditions of the family (USMP Islamic, 1995). Based on the understanding of the achievements put forward by experts, it can be said that mathematics learning achievement is the level of mastery achieved by students in following the teaching and learning process of mathematics in accordance with the stated goals. Achievement achievement by students is learning outcomes, student after following the teaching and learning process and is an interaction between several factors.

Mathematics teachers play an important role in encouraging students to have a positive attitude toward mathematics. A teacher's view of mathematics will be reflected in the learning he does. This will affect the quality of student learning but also how they consider themselves as mathematics students. Teachers and students directly negotiate between them the existence of behavioral norms in the classroom, and when those 
norms allow students to feel comfortable working on mathematics and share their ideas with others, they see themselves able to understand. Previous reports from the National Research Council identified the causes of poor school mathematics performance in the United States: The power of unlimited peer pressure often makes good performance in mathematics socially unacceptable. This environment of negative expectations is strongest among minorities and women who are most at risk during high school years when the first student makes choices in curricular purposes. Some of the most important consequences of failure of students to develop productive dispositions of mathematics occur in secondary schools, when they have the opportunity to avoid challenging math problems.

Students who have developed productive dispositions are confident in their knowledge and abilities. They see that mathematics is reasonable and understandable and believes that, with the right effort and experience, they can learn. It is counterproductive for students to believe that there are some mysterious "Math Competence" that determine their success in mathematics.

\section{Method}

A quantitative design, analysis based on PD score and mathematics test score will be followed by a qualitative design, analysis based on the observation made in this research. A total of 149 SMP Islamic Students in Jombang was procured as samples. They are SMP Islamic Students grade VIII and IX, since the PD instrument use Likert scale with the score one to four.

Table. Category Productive Disposition (Diknas, 2008)

\begin{tabular}{|c|c|}
\hline $\begin{array}{c}\text { Score of PD } \\
P D \leq 80 \% \text { of the } \\
\text { highest score }\end{array}$ & Interpretation \\
\hline $\begin{array}{c}70 \% \leq P D<80 \% \\
\text { of the highest score }\end{array}$ & High \\
\hline $\begin{array}{c}50 \% \leq P D<70 \% \\
\text { of the highest score }\end{array}$ & Low \\
\hline $\begin{array}{c}P D \leq 50 \% \text { of the } \\
\text { highest score }\end{array}$ & Very low \\
\hline
\end{tabular}

Furthermore, statistical analysis was based on the Spearman rank correlation and on the t-test.

\section{Quantitative Analysis}

After the total PD score of each SMP Islamic Students was counted, the result shown the category of each productive disposition aspect.

1. For enthusiastic in mathematics learning aspect the SMP Islamic students have the average score 7.6 or $63.3 \%$ of the highest score for this aspect. So, the students considered to have low enthusiastic in mathematics learning.

2. For attentive in mathematics learning, the SMP Islamic students have the average score 4.5 or $56.25 \%$ of the highest score for this aspect. So, the students considered to have low attendance in mathematics learning. 
3. For Persistent and diligent in dealing with problems aspect, the SMP Islamic students have the average score 8.0 or $66.67 \%$ of the highest score for this aspect. So, the students considered to have low Persistent and diligent in dealing with problems.

4. For full of confidence in learning and solving problems aspect, the SMP Islamic students have the average score 4.8 or $60 \%$ of the highest score for this aspect. So, the students considered to have low Full of confidence in learning and solving problems.

5. For flexible and open aspect, the SMP Islamic students have the average score 6.5 or $81.25 \%$ of the highest score for this aspect. So, the students considered to have high Flexible and open in mathematic problems.

6. For having high curiosity aspect, the SMP Islamic students have the average score 9.1 or $75.83 \%$ of the highest score for this aspect. So, the students considered to have high curiosity in mathematics.

7. For the ability to share opinions with others aspect, the SMP Islamic students have the average score 2.7 or $67.5 \%$ of the highest score for this aspect. So, the students considered to have low ability to share opinions with others in mathematics.

Generally, after counting the total PD score, only $4 \%$ of the students were considered to have a very high productive disposition, $33.6 \%$ have a high productive disposition, and the rest $62.4 \%$ have low productive disposition. On average, the productive disposition score was 66.92 or $66.92 \%$ of the highest PD score, considered as low. Another finding was that the mathematics achievement based on the test score on average was 67.44 , with the minimum score 15 and the maximum score 93. Furthermore, there was a significant correlation between students' productive disposition and students' mathematics achievement, correlation is significant at the 0.01 level (1-tailed) with the coefficient of correlation 0.278 .

\section{Qualitative Analysis}

The observation was made on student behavior inside and outside the classroom, on their responses and comments toward their mathematics learning experiences. Most students understand the importance of mathematics and they want to understand mathematics, like as they understood another subject. Another thing was, some students feel that the mathematics curriculum was most often condensed while the mathematical problems was complicated. Teacher meetings, seminars, and many other teacher business which causes the teacher absences from mathematics class, are some of the condensed curriculum courses, and students could not find source to ask how to solve complicated mathematic problem. Furthermore, there were times when students can understand the lesson easily, that is if their teacher implemented the right learning strategy (on their point of view), though the topic was hard. Reversely, they could not understand some of the topics, because they felt that their teacher could not explain the topics clearly, or the learning strategy was not attracted to them. Another finding was that SMP Islamic students use much of their time for social activities. These social activities take place in the school area and out of the school area. Sport activities take not only their energy, but their time as well. Social networks or online communities such as face book also take much of their time. Furthermore, SMP Islamic students whose are adolescence need some time for their partner, and this was an important thing for them. 


\section{Result and Discussion}

Productive disposition was a very important target because it will apparent in every aspect of their mathematical activities (NCTM, 1993). This research showed that there are positive correlation between productive disposition and mathematics achievement. This result was in mutual accord with the assumption that positive mathematical beliefs, attitudes, and feelings will lead to increased mathematical achievement (Grootenboer and Hemmings, 2007). Teachers must help students develop perseverance and broader their view of mathematics (Schackow, J.B. and Thompson, D.R.). This will increase student productive disposition, and because of the positive correlation with mathematics achievement, the mathematics achievement will be increased as well. Hopefully the level of Indonesian student mathematics achievement will be increased as well in the next TIMMS survey.

\section{Conclusion}

The productive disposition of Islamic Junior High School Students in this study was considered low, but had a significant and positive correlation with mathematics achievement, although the correlation coefficient was not high. Mathematics teachers must improve their ability to teach, be able to link mathematics material to environmental conditions. Applying more interesting learning strategies, give more time and attention in the classroom, engage with their students through online communities outside the classroom. Those are some of the efforts they can take to get their students' attention, and mathematics will be more satisfying for students.

\section{Acknowledgements}

I would like to express my deepest gratitude to my advisors, Prof. Dr. Rusijono and Dr. Fajar Arianto who guide me in conducting the research and also goes to IISTE which accept and publish the article.

\section{Reference}

NCTM (1993). Curriculum and Evaluation Standards for School Mathematics. The National Council Of Teachers Of Mathematics. Inc. USA. Schackow and Thompson (2011). High School Students' Attitudes Toward Mathematics. Exchange Quarterly. Find Articles.com. 20 October, 2018. http://findarticles.com/p/articles/mi hb3325/is_3 9/ai_n29219648/

Grootenboer and Hemmings (2007). Mathematics Performance and the Role Played by Affective and Background Factors. Mathematics Education Research Journal 2007, Vol. 19, No. 3, 3-20 http://www.merga.net.au/documents/MERJ_19_3_Grootenboer.pdf.

Diknas (2008). Pengembangan Perangkat Penilaian Afektif www.dikmenum.go.id. http://indraelbuguri.blogspot.com/2009/04/rangkuman-pendidikan-matematika-i.html.

Eka Lestari, K., Yudhanegara, R., dan Zarkasyi, W. (2015). Penelitian Pendidikan Matematika. Cetakan Pertama. Bandung: PT. Refika Aditama.

Lappan. (2009). Fostering A Good Productive Disposition.

NCTM News Bulletin.

www.nctm.org/about/content.aspx?id=1002. 